\title{
Kaliteli Çeviri Sorunu Üzerine
}

\author{
Leyla BABATÜRK ${ }^{1}$
}

\section{Öz}

Yabancı ülkelere seyahat etmek veya yabancı şirketlerle işbirliği yapmak gibi çağdaș dünyanın insanlara sunduğu firsatlar, tercümanlık mesleğine karşı duyulan ilginin artmasına sebep olmuştur. Dünyanın her köşesinde faaliyet gösteren çok sayıda tercüme bürosu müşterilere çeviri hizmeti sunmaktadır. Fakat ne yazık ki yapılan çevirilerin kalitesi her zaman yüksek seviyede değildir. Mevcut makalede çeviri bilimde yaygın olarak çeviri değerlendirmesinde kullanılan "eşdeğerlilik" ve "yeterlilik" kavramı üzerinde durulmuştur. Bazı bilim insanları tarafindan eşanlamlı olarak kullanılan kavramlar arasında farklılıklar mevcuttur. Bazı tercüme büroları ve şirketler tarafindan oluşturulan sistemler çeviri kalitesini ölçmek için yaygın olarak kullanılmaktadır. Bu sistemler çeviri metninde tespit edilen çeviri hataları üzerine kurulmuştur. Çünkü çeviri hatalarının sayısı, çeşitleri ve oranı çeviri kalitesini etkiler. Makalede çeviri kalitesinin neye göre ve ne açıdan değerlendirildiği hakkında bilgi verilmiştir. Ayrıca yukarıda belirtilen sistemler ve TQI (Çeviri Kalitesi İndeksi) gibi çeviri kalitesini etkileyen diğer hususlar hakkında bilgi içermektedir.

Anabtar Kelimeler: Kaliteli çeviri, Eşdeğerlilik, Yeterlilik, Uluslararası standartlar, Meslekî yeterlilik

\section{The Problem of Quality Translation}

\section{Abstract}

The modern world enables people to travel around the world and engage in trade with partners from different countries. Therefore, the need for qualified translators is growing every day. Translation agencies provide translation services around the world, however, translation quality is not always high. This article focuses on such basic concepts of translation studies as "equivalence" and "adequacy". Many scientists use these two terms synonymously. However, there is a difference between them. The article discusses how translation quality is assessed. There are certain translation quality assurance systems that some translation agencies or firms have developed. These quality assessment systems are widely used in the world. Translation quality assessment systems identify errors made by the translator, because the number of errors and their type directly affect the quality of the translation. This article contains information about the above assessment systems, as well as other factors affecting the quality of translation.

Key Words: High-quality translation, Equivalence, Adequacy, İnternational standards, Professional competence

\section{Atıf İçin / Please Cite As:}

Babatürk, L. (2021). Kaliteli çeviri sorunu üzerine. Manas Sosyal Araștırmalar Dergisi, 10(2), 1449-1456.

\footnotetext{
${ }^{1}$ Dr. - Kırgızistan-Türkiye Manas Üniversitesi Edebiyat Fakültesi, leyla.babaturk@manas.edu.kg

(iD ORCID: 0000-0003-3397-8147
} 


\section{Giriş}

Günümüzde birçok üniversite farklı programlarda çok sayıda tercümanlık eğitimi vermektedir. Her yıl değişik programlardan mezun olan çok sayıda tercüman vardır. Fakat gerçekten kaliteli tercüme yapabilen, hem kaynak hem de hedef dili çok iyi derecede bilip kullanabilen, kültürler arası iletişim becerisine sahip tercümanların sayısı azdır. Dolayısıyla tercümanlık büroları işin uzmanını aramak zorunda kalmaktadır. Mütercim-Tercümanlık bölümlerinde eğitim gören öğrencilerin yabancı dil bilme ve kullanabilme seviyeleri farklıdır. Çünkü her insanın belirli becerilere sahip olduğunu ve herkesin yabancı dil yeteneğinin farklı olduğunu unutmamak gerekir. Çeviri, hele sözlü olduğu zaman farklı beceri gerektiren oldukça stresli bir süreçtir. Bazı öğrenciler sözlü çeviriyi iyi yapar, bazıları ise yazılı çeviride çok başarllıdır. Bazı öğrenciler sadece ana diline iyi çeviri yapabilirler, diğerleri ise hem ana dillerine hem de yabancı dile gayet iyi çeviri yapabilmektedirler. Sözlü çeviri türleri ayrıca tercümanın sahip olması gereken beceriler gerektirmektedir. Dolayısıyla anında çeviriyi herkes yapamaz. Tercüman adaylarının kişisel özelliklerini de hesaba katmak gerekir. Bazı öğrenciler çok akıllı ama utangaçtır, dolayısıyla başkalarının önünde ardıl çeviri bile yapamayabilirler.

Yazılı çeviri tercümana düşünme, bilmediklerini araştırma, hatta yaptı̆ğ çeviri metninin redaksiyonunu yapma firsatı verir. Fakat günümüzde kaliteli yazılı çeviri yapabilecek tercümanlar bulmak güçtür. Çeviri büroları sahipleri veya çeviri yaptıranlar genellikle bu alandan uzak, yabancı dili bilmeyen, hatta çeviri süreci hakkında çok fazla bilgi sahibi olmayan insanlardır. Tercüman olmayan insanların bakış açısına göre çeviri yapmak için yabancı dili bilmek yeterlidir. Fakat çeviri işi görüldüğü kadar kolay değildir. Çünkü çeviri yapabilmek için sadece yabancı dili iyi derecede bilmek yetmez. Çeviri sürecinin kendine has kuralları, metotları, kriterleri ve işlevselliği mevcuttur.

Bilimsel literatürde "çeviri” kelimesi iki farklı anlamda kullanılmaktadır. İlk anlamı "zihinsel bir süreç", ikincisi ise "bu sürecin netices’" yani tercümanın yarattı̆̆ sözlü ya da yazılı erek metindir. Kelimenin iki anlamı birbirine bağlıdır. Çünkü ilki olmadan ikincisi zaten düşünülemez. Kaliteli çeviri problemi üzerinde araştırma yapanlar ise "çevirił" kelimesini süreç, sürecin neticesi bir de çeviri yaptıranlara sunulan hizmet olarak ele almaktadır. Kaliteli çeviri demişken insanın zihninde birtakım sorular oluşur; kaliteli çeviri nasıl bir çeviridir? Çeviri kalitesini ölçmek için belirli ölçütler var mıdır? Varsa çevirinin kaliteli sayılabilmesi için bu ölçütlere ne kadar uyulmalıdır? vs. (Thelen, 2009, s. 195-196). Bu tür sorulara cevap ararken bir başka sorun ortaya çıkmaktadır. Çeviri kalitesini ölçmek için kullanılan ölçütlerin belirli standardı bulunmamaktadır. Çünkü çeviri kalitesi ile ilgili müşteri ve redaktörlerin düşünceleri ya da beklentileri farklı olabilmektedir.

Bazı bilim insanlarına göre çeviri kalitesinin değerlendirilmesi temel ölçütlerden değişik şekillerde tanımlanan "eşdeğerlilik" ve "yeterlilik" kavramlarıdır. Fakat kaynak metin ile çeviri metnin karşılaştırılması temelinde oluşturulan ve yazılı çeviri kalitesinin değerlendirilmesinde kullanılan ölçütler vardır. $\mathrm{Bu}$ ölçütlerde çevirinin yapıldığı ortam, çevirinin yaptırılma amacı, çeviri esnasında başvurulan stratejiler hesaba katılmamaktadır (Petrova, 2009, s. 119-122).

\section{Çeviride Eşdeğerlilik ve Yeterlilik Kavramları}

Çeviri teorisinde tartışılan birçok konu "eşdeğerlilik" ve "yeterlilik" kavramlarının belirli tanımlarının bulunmamasından doğmaktadır. Bu tür konulardan bazıları şunlardır: Çeviri nedir; serbest çeviri ve kelime kelimesine çeviri arasındaki fark nedir, çevrilebilirlik, çevrilemezlik, tercüman sorumluluğu, anlam kayıplarının kaçınılmazlığı vs. (Garbovskiy, 2004, s. 316). "Çevirinin eşdeğerliliği”" kavramının net tanımı hâlâ yapılmamıştır ve bilim insanları bu kavramı değişik şekillerde tanımlamaktadırlar. Dolayısıyla "çeviri eşdeğerliliğ̣”" "çeviri yeterliliğı" ile karıştırılmakta ve bu iki farklı kavram eşanlamlı olarak sayılmaktadır.

"Çeviri eşdeğerliliğ̣” ve "çeviri yeterliliği” kavramları çağdaş çeviri teorisinin en önemli kavramlarındandır. Bu kavramlar birbiriyle bağlantılı olduğu için çoğu zaman eşanlamlı olarak kullanılır, ama söz konusu kavramlar farklı anlamlara sahiptir. Çeviride "eşdeğerlilik" kavramı, her şeyden önce kaynak metin ile çeviri metnin bazı ölçütler açısından eşit olduğu anlamına gelmektedir. Fakat çeviri, her zaman iki farklı dil arasında meydana gelen bir süreç olduğu için kaynak metnin ve çeviri metnin hem anlam hem şekil bakımından eşit olması mümkün değildir. Dolayısıyla çeviri teorisinde "eşdeğerlilik" kavramı farklı şekillerde yorumlanmaktadır: 1) Kaynak metin ile erek metindeki aktarılan bilgi eşitliliği (bilgi değişmezliği), 2) Kaynak ve çeviri metinlerin alıcı (okuyucu ya da dinleyici) üzerine yarattığı etki eşitliliği; 3) Çeviri metninde kaynak metnin anlam ve yap1 özelliklerinin korunması ve kaynak ve erek metinlerde aktarılan temel bilgi eşitliliği gerektiren şartların yerine getirilmesi; 4) Yeterli çeviri (kaynak 
metnin içeriği, kaynak metnin yapısal ile anlamsal özelliklerini koruyarak, hedef dilin kullanım kurallarını hesaba katarak eksiksiz bir şekilde aktarılması ve çeviri metnin alıcı üzerinde yarattığı etki kaynak metnin etkisi gibidir (Şamova, 2005, s. 173-179).

L. Latışev, çeviri kalitesinin ölçüm kriterlerinden birisi olan "eşdeğerlilik" kavramı yerine "en uygun çeviri şekli" ya da tercümanın başvurduğu "en uygun çeviri stratejisi” kavramlarını kullanmanın daha doğru olacağını belirtiyor. Dolayısıyla tercümanın her zaman aralarında seçim yapabilecek birkaç çeviri varyantı mevcuttur ve iyi tercüman en iyisini seçmek zorundadır. Yazara göre "eşdeğerlilik" tercümanın başvurduğu en iyi çeviri stratejisidir ve dolayısıyla tercüme sürecinin neticesini de etkilemektedir. "Yeterlilik" kavramı ise yazara göre en iyi çeviri varyantını seçmesine giden yol ya da en iyi çeviri stratejisini bulma yöntemidir. Böylece "çeviri yeterliliği", neticesi kaynak metne yapı ve anlam bakımından eşdeğer çeviri metni olan çeviri sürecinin ta kendisidir. Yeterli çeviri yapabilmek için tercümanların başvurdukları yöntemler bilimsel literatürde ana hatlarıyla tanımlanır. Çünkü tercüman en iyi çeviri varyantını seçebilmek için kullanacağı yöntemi kaynak metnin özelliklerine göre kendisi seçmek zorundadır (Latişev, 2005, s. 252- 263).

V. Komisarov'a göre diller arası iletişimin sağlanabilmesi için çeviri metnin her zaman kaynak metnin eşdeğeri olması şart değildir. Hatta bazı durumlarda özellikle yapısal eşdeğerlilik aranmayabilir. Bu yüzden yazara göre "yeterli çeviri", belirli iletişim durumunun gerektirdiği şart ve gerekçelere uyan çeviridir (Komisarov, 1999, s. 123). "Yeterli çeviri”, bir bakıma belirli oranda "eşdeğer" sayılabilir. Tercüman farklı iletişimsel durumlarda çeviri metnin "yeterliliğì" ile "eşdeğerliliği" arasındaki oranı kaynak metnin türüne, alıcı özelliklerine ve çeviri amacına göre ayarlar. Bu açıdan metnin türü ayrıca büyük önem taşır. Çünkü farklı metinleri çevirirken farklı stratejiler uygulanır. Örneğin tercüman edebî eserleri çevirirken hedef dilde adeta yeni edebî eser yaratmak zorunda kalır. Yeni edebî eser hedef dilin kullanım kurallarına göre yaratıldığı için çeviri esnasında kaynak metindeki bazı yapısal unsurlardan vazgeçilebilir. Teknik metinlerin çevirisinde ise tam tersi bir durum gözlemlenir. Kaynak metnin içerdiği bilginin eksiksiz olarak aktarılması ve böylece kaynak ve erek metinlerin yapı açısından olabildiğince eşdeğer olması gerekmektedir.

Çeviri teorisinde kullanılan iki temel kavram olan "çeviri eşdeğerliliğ̣”" ve "çeviri yeterliliğ̣" farklı anlam taşımaktadır. Fakat ikisi de çeviri kalitesinin değerlendirilmesinde önemli rol oynar. Çünkü bazı durumlarda çevirinin kaynak metne özellikle yapı bakımından eşdeğer olması gerekir, bazı durumlarda ise çevirinin yeterli olması istenir. Çevirinin nasıl olması gerektiğini çevrilen metnin türü, çeviri amacı ve alıcı (okuyucu veya dinleyici) özellikleri belirler. "Eşdeğer çeviri” genellikle kaynak metnin yapısal özellikleri korunarak yapılan çeviri olarak kabul edilir. Yeterli çeviride ise bu şart aranmaz. Üstelik "eşdeğer çeviri”" kavramı çeviri teorisinde daha çok edebî metin çevirisi, "yeterli çeviri”" kavramı ise genellikle edebî olmayan diğer tür metinlerin çeviri değerlendirilmesinde kullanılır. Mükemmel eşdeğer çeviri, kaynak ve çeviri metinlerin yapı, anlam, işlev vb. açıdan eșdeğer olmasını gerektirir. Fakat kaynak ile erek metnin her açıdan eşdeğer olabilmesi çeviri uygulamalarında nadir görünür. Yeterli çeviride ise çeviri amacı ve alıcı özellikleri öncelikli olduğu için kaynak ve çeviri metinlerin sadece anlam bakımından eşdeğer olması yeterli sayılabilir.

Çeviri redaksiyonu ile ilgili Rusça yazılmış birçok el kitabı bulunur. Bu el kitaplanı hem tercüman hem de editör odaklı olabilmektedir. Genellikle çeviri redaksiyonu ile ilgili kitaplarda çeviri metnin sahip olması gereken özelliklerden bahsedilir. Kabul edilebilir çevirinin, çeviri yaptıran kişinin taleplerini yerine getirmenin yanı sıra mutlaka "yeterli" olması gerekmektedir. "Çeviri yeterliliği” adı altında kaynak metnin taşıdığ anlamın eksiksiz bir şekilde aktarılması, bir kavramı karşılamak üzere birden fazla terimin kullanılmaması, çeviri metnin tamamının aynı üslup özellikleri taşıması, çeviri metinde çevrilmemiş yerlerin olmaması ve hedef dilin kullanım kurallarına uygun olması anlaşılmaktadır. Dolayısıyla kaliteli çevirinin en önemli değerlendirme kriteri çevirinin "yeterliliği” kabul edilir (Moiseenko, 2014, s. 6-7).

\section{Çeviri Kalitesinin Değerlendirilmesi}

Çeviri sürecinin neticesi olan kaliteli çeviri, herhangi başka bir ürün gibi belirli kriterlere uymalıdır. Dolayısıyla hem müşterileri hem işverenleri hem de tercümanları memnun edecek kriterleri belirleme sorunu ortaya çıkmaktadır. Başka bir deyişle, çeviri metnin nesi değerlendirilir ve yapılan çevirinin kalitesini değerlendirmek için nasıl bir metot kullanıllı? Her şeyden önce çeviri kalitesinin değerlendirilmesi neye göre yapılacak diye bakmak gerekir; müşterinin isteklerini yerine getirip getirmediğine mi bakılmalı yoksa kaynak ve çeviri metinlerindeki uyuşmazlıkların tespiti mi yapılmalı?

J. House, çeviri kalitesini iki farklı açıdan değerlendirmenin mümkün olduğunu vurguluyor: 1) Yapılan çevirinin eleştirisi (kalite kontrolü), 2) Tercümanın sahip olduğu ana dili ve yabancı dil ile ilgili bilgi birikimi ve tercümanlık mesleğinin gerektirdiği becerilerin değerlendirilmesi (House, 1997, s. 101-105). Dolayısıyla 
yapılan çevirinin iki farklı açıdan aynı anda değerlendirilebilmesi mümkünse ne kadar doğru olur? Sonuç itibariyle her müşteri "netice" olan çeviriyi (çeviri metni) değerlendirir. Tercümanın bilgi birikimi, sahip olduğu becerileri, çeviri yapmak için kullandığı çeviri stratejileri veya verdiği emeği kimse değerlendirmez. Aslında tercümanın kişisel özellikleri de çeviri sürecinde önemli rol oynamaktadır. 20. yy. sonlarında "tercüman değerlendirilmesi" "çeviri değerlendirilmesinin" bir parçası olarak kabul edilmiyordu. Fakat günümüzde tercümanın dakik olması, özverisi, takım içinde çalışabilmesi, başkalarını etkileme becerisi gibi kişisel özellikleri işverenlerin kararını belirleyecek faktörlerdendir.

Mütercim-Tercümanlık bölümünde verilen eğitimin temel amacı, öğrencilerin kaliteli ürün verebilmesi için (kaliteli çeviri yapabilmesi için) gereken becerileri oluşturup geliştirmektir. Hewson (1995) "Detecting cultural shifts: some notes on translation assessment" adlı makalesinde meslekî tercüman yeterliliğini iki farklı açıdan incelemektedir: 1) Yabancı dil yeterliliği 2) Yabancı kültür yeterliliği. Yabancı kültür yeterliliği, tercümanın farklı durumlarda farklı insanların beklentilerini (çeviri amacı) yerine getirmek üzere aracı olabilme becerisidir. C. Nord ise yabancı kültür yeterliliğinin gerektirdiği iki ek becerinin önemini vurgulamaktadır; bilgileri doğru bir şekilde aktarabilme ve en iyi tercüme varyantı bulma becerisidir. Bu beceriler tercümanın herhangi ek bilgilere başvurmadan çeviri yapabilmesi ile ilgilidir (Nord, 2005, s. 30-31).

L. Brunette (2000) "Towards a Terminology for Translation Quality Assessment" adlı makalesinde çevirinin beş açıdan değerlendirilmesi gerektiğinden bahsediyor. Yazarın belirttiği hususlar aslında çeviri kontrolünün aşamalarıdır: 1) Pragmatik redaksiyon, 2) Kalite değerlendirilmesi, 3) Kalite kontrolü, 4) Yeniden bakış 5) Didaktik redaksiyon. Çeviri redaksiyonu yapılırken editör genellikle bir takım tercüme hatalarını (anlam bozukluğu, üslup hataları, gramer hataları, imla hataları, kelime kelimesine çeviri, ima ve mecazî ifadelerin doğru aktarılması, gramer kurallarına uyulması vb.) tespit edip düzeltmeye çalışı. Fakat çevirideki hataların tespiti ve bu hataların nedenleri hakkında bilgi vermez. Yani editör neden bu hata yapıldı ve yapılan hata çeviri için ne kadar önemli diye düşünmez. Fakat çeviri sürecinin değerlendirilmesi, yapılan çeviri hatalarının nedenlerinin araştırılması çeviri kalitesi değerlendirilirken hesaba katılmalıdır.

Çeviri kalitesini değerlendirmede kullanılabilir "anahtar" (ideal) çeviri metni bulunamaz. Çünkü çeviri, tercümandan yaratıclık isteyen bir süreçtir. Dolayısıyla bir ana fikir birçok farklı şekilde dile getirilebilir. Bu durum tamamıla hedef dilin zenginliği ve tercümanın o dili kullanma becerisine bağlıdır. Yapılan çevirinin değerlendirilmesi genellikle çeviri metninde rastlanan çeviri hatalarının analiziyle başlar. Böylece yapılan çeviri neye göre iyi ya da neye göre kötü yapılmıştır diye (ya da ne kadar iyi ve ne kadar kötü yapıldı diye) bakilir.

\section{Uluslararası Çeviri Kalite Standartları}

Çeviri bilimde çeviri kalitesini değerlendirme ve ölçme sorunu 1970’li ylllardan beri güncelliğini korumaktadır. O yıllarda çevirinin (çeviri metnin) ne kadar iyi olduğunu saptama ihtiyacı doğmuştur. Dolayısıyla bu sorunu çözmek üzere bir takım yöntemler geliştirilmiştir. Tüm bu yöntemleri iki büyük gruba ayırmak mümkündür: 1) Kantitatif (sayısal) yöntemler 2) Kantitatif olmayan (sayısal olmayan) yöntemler. Fakat belirtmek gerekir ki, birinci ve ikinci gruba giren yöntemler farklı metin türleri için uygulanabilir. Çevrilen metinleri de oldukça farklı üslup özelliklerinden yola çıkarak edebî metinler ve teknik metinler adı altında iki büyük gruba ayırmak mümkündür. Fakat basın (medya) metinleri hem edebî hem de bilimsel dil ve üslup özellikleri taşıyabilir. Dolayısıyla basın metinlerinin değerlendirilmesinde hangi grup yöntemlerinin kullanılması gerektiği hala üzerinde tartışılan konularından biridir.

Çeviri kalitesinin sayısal yönden değerlendirme modelleri genellikle belirli kurumlar için geliştirilmiştir. $\mathrm{Bu}$ değerlendirme modellerine göre çeviri metinden bir ya da birkaç farklı parça (çeviri hatalarının tespit edildiği / edilemediği) seçilir. Sonra ise çeviri metinde tespit edilen hataların türüne ve oranına göre kabul edilebilir ya da kabul edilemez olduğu hakkında karar verilir.

Çeviri kalitesini değerlendirmede kullanılan ölçütleri geliştiren ilk kurum Canadian Translation Bureau (Kanada Devlet Tercüme Bürosu) olmuştur. Bu kurum Sical (Canadian Language Quality Assessment System / Kanada Dil Kalitesini Değerlendirme Sistemi) modeli geliştirmiştir. Bu modele göre yapılan çeviri kalitesi, 400 kelimelik çeviri metninin kalite seviyesi (A, B, C, D) belirlenir. Metinde tespit edilen hatalar çeviri hataları, dil kullanım hataları, önemli hatalar ve önemsiz hatalar 4 gruba ayrılır ve metindeki oranları belirlenir (Williams, 2004, s. 3). Bu sisteme göre en kaliteli çeviri metni, hiç önemli hatası tespit edilememiş ve en fazla 6 önemsiz hata tespit edilmiş metin kabul edilir. Kabul edilebilir çeviri ise 0 önemli ve en fazla 12 önemsiz hata bulunan metindir. Eğer metinde 1 önemli ve 18 önemsiz hata tespit edilirse 
yine de orta kaliteli çeviri olarak sayılır ama redaksiyonu mutlaka istenir. Eğer metinde 1'den fazla önemli hata ve $18^{\prime}$ den fazla önemsiz hata tespit edilirse çeviri kalitesiz sayllır ve kabul edilemez.

Araba üretimi alanında faaliyet gösteren SAE şirketi, teknik metin çevirilerinin kalite kontrolü için kendi değerlendirme sistemini geliştirmiştir. Bu sisteme göre çeviri hataları şu gruplara ayrılmaktadır: Yanlış çevrilmiş terimler, sentaktik hatalar, boşluklar (çevrilmemiş kelimeler), morfolojik hatalar, teknik hatalar, imla hataları, hedef dil açısından yanlış olabilecek diğer hatalar (www.apex-translations.com). Bunun yanı sıra her gruptaki çeviri hatalarını da iki alt gruba ayırmaktalar: Önemli ve önemsiz hatalar. Ayrıca her grubun hataları için puan verilir. Mesela yanlış terim grubundan önemli hata 5, yanlış terim grubundan önemsiz hata ise 2 puandır. Görüldüğ̈ gibi ne kadar çok önemli hata tespit edilirse, çeviri kalitesi o kadar düşük olacaktır. Bu kalite kontrol sistemini geliştirenler, sistemin araba sanayi alanı için geliştirildiğini ve teknik metinler için uygun olduğunu, dolayısıyla söz sanatları, mecaz anlam içeren metinler için uygun olmadı̆̆ını belirtmektedirler.

American Translators Association (Amerika Tercüman Derneği) geliştirdiği kalite kontrol sisteminde 24 çeşit çeviri hatası belirlenmiştir. Mesela, kaynak metinde bulunmayan bilgi, ifadelerin çok anlamlilığı gibi hatalardır. Ama bu kalite kontrol sistemi pek kullanışlı sayılmaz. Çünkü çok fazla hata çeşidi belirlenmiştir. Üstelik belirlenen hataların net ve anlaşılır tanımlarını bilimsel literatürde her zaman bulmak mümkün değildir. Bu nedenle çeviri kontrolü yapan kişi zor durumda kalabilir (www.studfile.net).

Edebî olmayan metinler için en uygun ve kullanışl kalite kontrol sistemi LíSA (the Localization Industry Standards Association) sayılabilir. Bu model bir tablo şeklindedir. Dolayısıyla model kullanımı özel geliştirilen bilgisayar programı aracılığılla kullanılmaya uygundur. Hata çeşidi fazladır ve her hata çeşidinin taşıdığ öneme göre 3 alt grubu mevcuttur: Önemsiz hata, önemli hata, kabul edilemez hata. Çeviri kalitesi ise seçilen metin parçasında tespit edilmiş hataların sayısına göre belirli formül kullanarak çeviri kalitesi indeksi saptanarak belirlenir (www.lisa.org).

Delpech E. M. (2014) "Comparable Corpora and Computer-assisted Translation" adlı kitabinda sayısal kalite kontrol modellerine karşı sayısal olmayan modellerin geliştirildiğinden bahsetmektedir. Bu modellere göre bir metnin çeviri kalitesi, metinden bir parça seçerek ve bazı kelime ya da cümlelerdeki hataların sayısını hesaba katarak saptanmaz. Metin bir bütündür, ama sayısal modellerde bu bütünlük bozulmaktadır. K. Rais, metinleri işlev ve üslup özelliklerine göre 4 gruba ayırarak değerlendirmek gerektiğini belirtmektedir. Birinci gruba içerik odaklı metinler girer. Bu gruba giren metinlerin içerdiği bilgilerin eksiksiz bir şekilde aktarılması önem taşımaktadır. Mesela, gazete haberleri, bilimsel makaleler vb. İkinci gruba şekil odaklı metinler girer. Bu tür metinlerin çevirisinde onların estetik açıdan şekli önemlidir. Mesela, edebî eserler ve şiirler bu gruba giren metinlerdendir. Üçüncü grubu psikolojik etki odaklı metinler oluşturmaktadır. Bu tür metinlerin çevirisinin temel amacı, alıcı üzerinde yarattığı etki orijinal metnin yarattığı ile aynı olmasıdır. Bu gruba reklam ve propaganda içeren metinler girer. En son gruba ise medya metinleri, yazılı olmayan metinler (piyes, sözlü konuşmalar vb.) girmektedir. Böylece K. Rais çeviri kalitesinin değerlendirilmesi için kaynak metnin taşıdığı anlamsal ve yapısal özelliklerinin önem taşıdığını vurgulamaktadır. Yazar, çeviri hatalarını ise lengüistik (leksik, anlamsal, gramer hataları) ve lengüistik dışı (üslup özellikleriyle ilgili hatalar) olarak iki gruba ayırmaktadır. İkinci gruba giren hatalar iletişim özellikleri, çevirinin yapıldığı ortam, zaman veya yer ile ilgili olan hatalardır.

Görüldüğü gibi sayısal olmayan yaklaşım dilin estetik yanlarını yansıtan metinler için geçerlidir. Fakat bu tür metinlerin çeviri kalitesini kontrol eden bir sistem henüz geliştirilmiş değildir. Muhtemelen bu durum her dilin kendine has zenginliğinden ve kelimelerin farklı anlamlarda kullanılabilmesinden kaynaklanmaktadır. Çünkü bir kelime hangi anlamlarda kullanılabilir diye saptamak mümkün değildir. Farklı insanlar, farklı sosyal gruplar aynı kelimeyi oldukça farklı anlamlarda kullanabilir.

Rus çeviri bilimcilerin de çeviri kalitesi sorunu ile ilgili çeşitli görüşleri vardır. Çeviri teorisi alanında bilimsel faaliyetlerde bulunanlara göre çeviri kalitesinin değerlendirilmesinde çevirinin "eşdeğerliliği” ve "yeterliliği” ayrıca önem taşımaktadır. Çeviri yeterliliği, çeviri metnin bütününü kapsar. Ayrıca kaynak ile çeviri metinlerin içeriği, iletişimsel ve pragmatik, işlevsel ve üslup özellikleri açısından denk gelmesi gerekir. Kaynak ile çeviri metinlerin eşdeğerliliği ise, metinlerin hem bütününü hem de ayrı parçaları (kelime, ifade, cümle) kapsar.

V. Krupnov da çeviri kalitesini değerlendirme yaklaşımları üzerinde bilimsel araştırma yapan biridir. Ona göre çeviri kalitesi değerlendirilmesi dört aşamada yapılmalıdır. Birinci aşama, kelime ve kelime 
gruplarının çeviri kalitesinin değerlendirilmesidir. İkinci aşama cümlelerin ve böylece çeviri metnin bir bütün olarak çeviri kalitesinin değerlendirilmesidir. Üçüncü aşama kaynak metinde ifade edilen duyguların, imaların ve üslup özelliklerinin aktarılma kalitesinin değerlendirilmesidir. Dördüncü aşama ise çeviri metnin kaynak metin gibi "kulağa hoş gelip gelmediğinin” değerlendirilmesidir (Krupnov, 1976, s. 58-61).

Rusya'da tercüme bürolarında yapılan çeviri kalitesini değerlendirmede Kantitatif (sayısal) yaklaşım yaygındır. Genellikle Rusya’da LISA modeli kullanılır ve çeviri kalitesi TQI (Translation Quality Index / Çeviri Kalitesi İndeksi) temelinde değerlendirilir. TQI belirli formül aracılığıyla hesaplanırken çeviri metinde tespit edilen hataların toplam puanı toplam kelime sayısına bölünür ve böylece çeviri metnin doğruluk oranı belirlenir. Hatalar ise çeviri açısından taşıdığı anlam esasına göre üç gruba ayrılır: Önemsiz hatalar, düzeltilebilir (orta) hatalar ve kabul edilemez hatalar. Çeviride rastlanan hatalar başka açıdan da üç farklı gruba ayrılır: 1) Kaynak dil kullanma hataları (imla hataları, gramer hataları, yanlış kelime seçimi, deyim grubunun yanlış çevirisi vb.) 2) Anlam hataları (anlam kaybı, anlam değişmesi vb.). Bu tür hataların çeviri kalitesi açısından ne kadar önem taşıdığı hakkında editör karar verir. 3) Terminoloji hataları (eşdeğer terimlerin kullanılmaması). TQI yüzdeler üzerinde hesaplanır ve çeviri kalitesinin belirlenen standartlara uyup uymadığına bakılır. Pekiyi $\% 98-100$, İyi \%095-97, orta \% 90-94 ve \%90 ve daha düşük TQI olan çeviriler kabul edilmemektedir (Albukova, 2016, s. 66-68).

\section{Sonuç ve Öneriler}

Meslekî eğitim almış tercümanların sayısı günden güne artmaktadır. Fakat buna rağmen yapılan tercümelerin kalitesi oldukça düşüktür. Dolayısıyla tercüme yaptıranlar yüksek kaliteli tercüme yapabilen işin uzmanını aramak zorunda kalmaktadır. Böyle bir durumun mevcut olması değişik faktörlerden kaynaklanmaktadır. Yükseköğretim kurumlarında alınan eğitim kalitesi, tercümanların kişisel özellikleri ve meslekî yeterlilikleri, hatta çeviri yaptıranların veya tercüme bürolarının "kaliteli çevirì" anlayışı ve çeviri metni için oluşturdukları standartlar yapılan çevirinin kalitesini etkilemektedir.

Çeviri bilimciler, çeviri kalitesini iki temel kavramı (çevirinin eşdeğer olması ve yeterli olması) esasa alarak değerlendirirler. Fakat çeviri metin her açıdan kaynak metnin eşdeğeri olamaz. Bazı durumlarda ise eşdeğer sayılabilecek çeviri yeterli olamayabilir. Dolayısıyla tercüman her zaman çeviri metnin hem anlam hem de yapı bakımından en yakın varyantını yaratmaya çalışmalıdır. Çünkü tercümanın temel amacı, kaynak metnin içeriğini aktarmada anlamların sırasını doğru belirlemek ve eksiksiz hedef dile aktarmaktır. Tercüman çeviri yaparken neyin mutlaka aktarılması gerektiğini ve anlam kaybı yaşanmaması için neden vazgeçebileceğini iyi bilmelidir. Dolayısıyla her tercüman kaynak metindeki en önemli bilgiyi doğru tespit etmek zorundadır. Vazgeçilebilecek unsurların belirlenmesinde kaynak metnin türü, çevirinin ne amaçla yapıldığı ve alıcının kim olduğu (nasıl biri olduğu) ayrıca önem taşımaktadır. Maalesef çağdaş çeviri bilim çalışmalarında en iyi çeviri varyantını elde etmek için tercümanların başvurabilecekleri strateji oluşturma algoritması bulmak mümkün değildir. Durum öyle olsa da tercümanlar en iyi çeviri varyantını seçmek için kaynak ve çeviri metinlerin benzer yapısal ve anlamsal özelliklerinin korunması ve çeviri metnin alıcı üzerinde benzer etki yaratabilme potansiyelini göz önünde bulundurmalıdır.

Tercümanın kişisel özellikleri hem çeviri sürecini hem de neticesini etkileyen fakat arka planda kalmış önemli faktördür. Dolayısıyla tercümanları eğitenler, meslekî yeterlilik için tercümanların sahip olması gereken becerileri geliştirmek için çaba sarf etmelidir. Çünkü tercümanın sahip olduğu meslekî yeterlilik, çeviri kalitesini düpedüz etkileyen faktördür. Dolayısıyla tercümanlar, çeviri yaptıkları dillerin işlevsel ile bilişsel özellikleri ve o dilleri konuşan halkların kültürleri açısından ne kadar kendilerini geliştirirlerse çeviri kalitesi o kadar yükselecektir.

\section{Etik Beyan}

"Kaliteli Çeviri Sorunu Üzerine” başlıklı çalışmanın yazım sürecinde bilimsel kurallara, etik ve alıntı kurallarına uyulmuş; toplanan veriler üzerinde herhangi bir tahrifat yapılmamış ve bu çalş̧ma herhangi başka bir akademik yayın ortamına değerlendirme için gönderilmemiştir. Bu araştırmada derleme türünde olduğu için etik kurul kararı zorunluluğu bulunmamaktadır.

\section{Kaynakça}

Albukova, O. (2016). Obzor suşçestvuyuşçih podhodov k probleme otsenki kaçestva perevoda. Filologiçeskiye Nauki. Voprosi teprii i praktiki. № 4(58), Tambov: Grammota, 65-69.

Brunette, L. (2000). Towards a Terminology for Translation Quality Assessment. The Translator. Studies in Intercultural Communication. Evaluation and Translation. Special Issue. St. Jerome Publishing, Manchester, Vol. 6. N 2, 169-182.

Delpech E. M. (2014). Comparable Corpora and Computer-assisted Translation. London: ISTE Ltd. 
Hewson, L. (1995). Detecting cultural shifts: some notes on translation assessment. Cross-Words. Issues and Debates in Literary and Non-literary Translating. Liège: L3-Liège Language and Literature, 101-108.

House, J. A. (1997). Translation Quality Assessment: a model revisited. Tübingen: Narr.

Nord, C. (2005). Text Analysis in Translation. Theory, Methodology, and Didactic Application of a Model for Translation-Oriented Text Analysis. Second Edition, Amsterdam- New York: Rodopi.

SEA Translation Quality Metric. URL: http://www.apex-translations.com/documents/sae_ j2450.pdf (20.08.2020)

LIS A (Localization International Standards Association) URL: http://www.lisa.org/ (20.08.2020)

Thelen, M. (2009). Quality Management for Translation. CIUTI-Forum 2008: Enhancing Translation Quality: Ways, Means, Methods. Bern: Peter Lang, 195-212.

Williams M. (2004). Translation Quality Assessment: An Argumentation-Centered Approach. Ottawa: University of Ottawa Press.

Albukova O. V. (2016). Obzor suşçestvuyuşçih podhodov k probleme otsenki kaçestva perevoda. Filologiçeskiye nauki. Voprosi teorii i praktiki. Tambov: Gramota, № 4(58), 65-69.

Garbovskiy N. K. (2007). Teoriya Perevoda. Moskva: İzdatelstvo MU.

Komisarov V. N. (1999). Sovremennoye perevodovedeniye. Moskva: ETS.

Krupnov V. N. (1976). V tvorçeskoy laboratorii perevodçika. Oçerki po prof.perevodu. Moskva: Mejdunarodnıye otnoşeniya.

Latışev L. K. (2005). Tehnologiya perevoda. Moskva: İzdatelskiy Tsentr "Akademiya”.

Moiseenko G. (2016). Praktiçeskiy spravocnik perevodsika i redaktora. Moskva.

Petrova O. V. (2009). Suşçestvuyut li universalnıye kriterii otsenki kaçestva perevoda? Vestnik VGU. Seriya Lingvistika i mejdunarodnaya kommunikatsiya, № 2, 119-123.

Tişin D. O. O priyomah formalizovannoy otsenki kaçestva perevoda. Soyuz perevodçikov Rossii. Sankt- Peterburgskoye otdeleniye. URL: https:/ / studfile.net/preview/3302414/ (25.19.2020).

Şamova N. V. (2005). Razgraniçeniye ponyatiy “ekvivalentnost” i “adekvatnost” v perevode. Vestnik MGU. Seriya 19. Lingvistika i mejkulturnaya kommunikatsiya, № 2, 171-180.

\section{EXTENDED ABSTRACT}

There are a lot of universities in the world that train future translators. Therefore, every year there is a huge number of professional translators who graduate from their institutions. However in spite of this, it is not so easy to find a professional translator who would know the language and culture of the target language as well as the source language. It is caused not only by the quality of education that a future translator received in university, but because certain skills and abilities of a translator, as well as his or her personal qualities are also very important for a quality translation.

In the scientific literature, the word "translation" is used in two meanings: "process" and "result" of this process. Both concepts are inseparable from each other, since the presence of one implies the presence of the other. However for most people translation is a result i.e. a text in the target language and very often the word "high-quality translation" means the compliance of the translation text with the norms and usage of the target language. It should also be noted that the quality of translation can be assessed both by professionals and by those who commissioned translation.

Two terms are used as criteria for assessing translation quality. They are "equivalent translation" and "adequate translation". Many scientists use these two words as synonyms. However, their meaning is different, because an "equivalent translation" is a translation that retains not only the main meaning of the original, but also at a certain extent the stylistic and constructive features of the original text. "Adequate translation" is a translation that has the same effect on the recipient as the original text. Both concepts are keys in evaluating translation quality. However, the concept that prevails in the assessment is determined by the type of text, since the priority of evaluating the translation quality changes according to a type of the source text. For example, the translation of a technical text shall not be compared with the translation of a fictional work, because the first one should be maximally equivalent to the original and the second should be maximally adequate and have the same effect on the reader as the original. Thus, it can be said that the translation of any text cannot be equally equivalent and adequate.

What formed the basis for assessment of the translation quality and what methods are used for this purpose? Some scholars point out that not only the quality of the translation text should be assessed, but also the factors that influence the translation process. The first case implies criticism of the translation, and the second, implies an assessment of the quality of the translation process itself. The factors that directly affect this process are the level of the translator's proficiency in his or her native and foreign languages, as well as certain skills that are necessary to carry out a particular type of translation. Each translator must have a certain set of knowledge about the language and culture both in the native and foreign languages (target language). 
Since translation activities are getting more popular day by day and have become a part of all spheres of human activity, it became necessary to control the quality of the translations provided. Certain methods have been developed in order to solve the problem of assessing the translation quality. These methods can be divided into two main groups. The first group includes quantitative assessment methods, and the second group includes non-quantitate assessment methods. Different types of texts can be assessed using different methods, based on their stylistic features texts can be divided into technical and artistic texts. Quantitative methods for assessing translation quality have been developed for specific organizations. According to such methods, the number of translation errors is counted in the translation text or in a certain passage of the text; these errors are assessed according to certain criteria. The translation quality is determined according to a certain scale depending on the quantitative ratio of errors in relation to the entire translated text. The first organization to develop criteria that a quality translation must meet was the Canadian Translation Bureau. This organization developed the Canadian Language Quality Assessment System model. According to this model, the quality of a translation is assessed on a four-tier scale. An excerpt from the text of 400 words is selected to assess the translation. Errors that were identified in the translation text are divided into 4 groups, which are also internally divided into important and unimportant errors. Thus, a translation of the highest quality should not have any important mistakes, however up to 6 unimportant mistakes are allowed. A translation in which more than one important mistake and more than 18 unimportant mistakes are made is considered to be of poor quality. Several more models similar to this were developed; they are being used successfully in control of technical texts' translation quality.

Non-quantitative assessment methods can be applied in assessment of literary texts' translation quality, since the supporters of these methods believe that it is not enough to assess the quality of the translation of a certain passage to define quality of the whole text and that the entire translation should be evaluated. Therefore, supporters of non-quantative methods divide texts into 4 groups, based on their functional and stylistic features. The first group includes texts in which it is the most important to transmit the information contained, for example scientific articles or magazine news. The second group includes texts, translation of which first of all shall preserve their aesthetic qualities, for example: literary works and poetry. The third group includes texts that should have a certain impact on the addressee; these are advertising texts or texts with elements of propaganda. The last group includes media texts, for example oral presentations made by speakers.

In Russian translation agencies, translation quality assessment is determined based on the calculation of the Translation Quality Index according to the LISA model. Translation errors are divided into different groups and each error class has its own score for assessment. Translation Quality Index is calculated as a percentage, therefore a translation of the highest quality is considered to have a Translation Quality Index of $98-100 \%$. A translation with a Translation Quality Index below $90 \%$ is considered to be of poor quality.

When assessing the quality of translation, the focus is put on the translated text, the number of errors made by the translator and their percentage. However, this type of quality assessment does not provide information on the reasons of translation errors. Since in translation studies translation is generally considered to be not only the text of the translation, but also the process itself, assessing the quality one should also take into account the factors that can influence the implementation of this process. 